\title{
Feeding sunflower oil to partially defaunate the rumen increases nitrogen retention, urea-nitrogen recycling to the gastrointestinal tract and the anabolic use of recycled urea-nitrogen in growing lambs
}

\author{
Kiran Doranalli and Timothy Mutsvangwa* \\ Department of Animal and Poultry Science, University of Saskatchewan, Saskatoon, SK, Canada, S7N $5 A 8$ \\ (Received 31 March 2010 - Revised 5 November 2010 - Accepted 12 November 2010 - First published online 24 January 2011)
}

\begin{abstract}
The objective of the present study was to delineate how interactions between feeding sunflower oil (SFO) to partially defaunate the rumen and altering dietary ruminally fermentable carbohydrate may alter urea-N kinetics and $\mathrm{N}$ metabolism in lambs. In a $4 \times 4$ Latin square with a $2 \times 2$ factorial arrangement of treatments, four Suffolk ram lambs $(61.5(\mathrm{sE} 4.0) \mathrm{kg})$ were used. Treatments were $0(-\mathrm{SFO}) v .6 \%(+\mathrm{SFO})$ SFO and dry-rolled barley (DRB) $v$. pelleted barley (PB). N balance was measured over $4 \mathrm{~d}$, with concurrent measurement of urea-N kinetics using continuous intra-jugular infusions of $\left[{ }^{15} \mathrm{~N}^{15} \mathrm{~N}\right]$ urea. Feeding $\mathrm{SFO}$ decreased $(P=0 \cdot 001)$ ruminal protozoa and $\mathrm{NH}_{3}-\mathrm{N}$ concentrations. Urinary $\mathrm{N}$ excretion was lower $(P=0.003)$, and retained $\mathrm{N}$ was higher $(P=0.002)$ in $+\mathrm{SFO}$ lambs compared with $-\mathrm{SFO}$ lambs. Endogenous production of urea-N (urea-N entry rate; UER) was similar across treatments. Urea-N transfer to the gastrointestinal tract (GIT) (GIT entry rate; GER), expressed as absolute amounts $(16.4 v \cdot 13.1 \mathrm{~g} / \mathrm{d}$ ) or as a proportion of the UER $(0.693 v .0 .570)$, its anabolic use $(9.0 v \cdot 6 \cdot 0 \mathrm{~g} / \mathrm{d})$ and microbial $\mathrm{N}$ supply $(14.6 v \cdot 10 \cdot 9 \mathrm{~g} / \mathrm{d})$ were higher $(P \leq 0 \cdot 001)$ in + SFO lambs compared with $-\mathrm{SFO}$ lambs. As a proportion of the UER, GER was higher, whereas urinary urea-N loss was lower, in lambs fed PB compared with those fed DRB $(P=0 \cdot 01)$. In summary, feeding SFO increased urea-N recycling to the GIT and microbial non- $\mathrm{NH}_{3}-\mathrm{N}$ supply, thus providing new evidence that the improved efficiency of $\mathrm{N}$ utilization in partially defaunated ruminants could be partly mediated by an increase in urea-N recycling.
\end{abstract}

Key words: Partial defaunation: Microbial protein synthesis: Nitrogen metabolism: Sheep: Urea-nitrogen recycling

In ruminants, it is well recognised that endogenous urea-N production often exceeds apparent digestible $\mathrm{N}$ intake, yet ruminants still maintain a positive $\mathrm{N}$ balance by recycling $40-80 \%$ of this urea-N to the gastrointestinal tract $(\mathrm{GIT})^{(1)}$. Urea-N that passes into the rumen can provide ruminally available $\mathrm{N}$ for the synthesis of microbial protein, which is a major contributor to the metabolisable protein that is available for intestinal digestion ${ }^{(1)}$. Recently, we have demonstrated that feeding linoleic acid-rich sunflower oil (SFO) to partially defaunate the rumen was associated with (1) an increase in the proportion of endogenous urea-N that was recycled to the GIT and (2) a tendency to increase the proportion of recycled urea-N that was utilised for anabolic purposes ${ }^{(2)}$. Previously, the removal of protozoa (i.e. defaunation) has been reported to improve $\mathrm{N}$ utilisation, mainly by decreasing the ruminal $\mathrm{NH}_{3}-\mathrm{N}$ pool, coupled with a greater sequestration of $\mathrm{NH}_{3}-\mathrm{N}$ into bacterial protein ${ }^{(3)}$, and by decreasing intra-ruminal $\mathrm{N}$ recycling ${ }^{(4)}$. Our previous work showed that the positive effects of defaunation on $\mathrm{N}$ utilisation may also result from an increase in urea-N recycling to the rumen ${ }^{(2)}$ Because defaunation decreases the ruminal $\mathrm{NH}_{3}-\mathrm{N}$ level ${ }^{(4)}$, this could potentially increase transepithelial urea-N transfer as the ruminal $\mathrm{NH}_{3}-\mathrm{N}$ level is negatively correlated with urea-N transfer into the rumen ${ }^{(5)}$. In addition, transepithelial movement of urea-N by passive diffusion into the rumen is facilitated by bacterial urease activity, which maintains a favourable concentration gradient ${ }^{(6)}$. Cheng \& Wallace ${ }^{(7)}$ demonstrated that urease activity in ruminal contents was negatively correlated with the ruminal $\mathrm{NH}_{3}-\mathrm{N}$ level.

Although the present results showed that a higher proportion of endogenous urea-N production was recycled to the GIT in partially defaunated ruminants, $\mathrm{N}$ intake differed due to protozoal status in that study as a result of decreased DM intake ${ }^{(2)}$. Because of the positive correlation between $\mathrm{N}$ intake and hepatic output of urea- $\mathrm{N}^{(8,9)}$, data on urea-N recycling kinetics could have been confounded due to differences

Abbreviations: DRB, dry-rolled barley; GER, gastrointestinal entry rate; GIT, gastrointestinal tract; NAN, non-NH $3-\mathrm{N}$; OM, organic matter; PB, pelleted barley; PD, purine derivative; PUN, plasma urea-N; RFC, ruminally fermentable carbohydrate; ROC, urea-N that re-enters the ornithine cycle; SFO, sunflower oil; UER, urea-N entry rate; UFE, urea-N to faecal excretion; UT-B, urea transporter-B; UUA, urea-N utilised for anabolic purposes; VFA, volatile fatty acid. 
in $\mathrm{N}$ intake. In addition, the use of recycled urea-N for anabolic purposes showed only a tendency to be higher in partially defaunated animals compared with faunated animals $^{(2)}$, suggesting that ruminal energy supply might have limited microbial use of recycled urea-N for protein synthesis. Increasing dietary amounts of ruminally fermentable carbohydrate $(\mathrm{RFC})^{(10)}$ or shifting carbohydrate digestion from the small intestine to the rumen via steam-flaking compared with dry-rolling of sorghum grain ${ }^{(11)}$ has been shown to increase urea-N transfer to the rumen, in addition to increasing $\mathrm{N}$ sequestration into microbial protein as energy supply from RFC is the major driver for microbial growth ${ }^{(12,13)}$. Also, substantial decreases in ruminal protozoal populations have been reported in ruminants fed high-grain diets or extensively processed barley ${ }^{(13,14)}$. Providing more RFC, therefore, could improve $\mathrm{N}$ utilisation by stimulating both urea- $\mathrm{N}$ recycling to the GIT and microbial protein production. In western Canada and parts of the northern USA, barley grain is the principal cereal grain that is included in ruminant diets, and it is commonly fed either in a dry-rolled or in a pelleted form. Pelleting decreases particle size, thus shifting the site of carbohydrate digestion from post-ruminal sites to the rumen, and previous in situ studies in our laboratory have clearly indicated a higher soluble starch fraction, a higher degradation rate of the degradable starch fraction and a higher effective starch degradability of pelleted barley (PB) when compared with dry-rolled barley (DRB) ${ }^{(15)}$. Based on this previous study, it can be expected that ruminal starch digestibility would be higher for PB compared with DRB, which could potentially alter urea-N recycling to the GIT and microbial protein synthesis in the rumen.

The major objective of the present study was to delineate how interactions between feeding SFO to partially defaunate the rumen and altering dietary RFC may alter urea-N kinetics and $\mathrm{N}$ metabolism in growing lambs. We hypothesised that feeding SFO to partially defaunate the rumen would increase urea-N recycling to the GIT and the utilisation of recycled urea-N for anabolic purposes, and that these effects would be more pronounced if ruminal energy supply was increased by feeding PB compared with DRB.

\section{Materials and methods}

Lambs that were used in the present study were cared for and handled in accordance with the guidelines of the Canadian Council of Animal Care ${ }^{(16)}$, and their use was approved by the University of Saskatchewan Animal Care Committee (UCACS protocol no. 20040048).

\section{Animals and experimental design}

A total of four Suffolk ram lambs $(61.5$ (SE 4.0) kg initial body weight) that were fitted with ruminal cannulae were used. The experiment was run as a $4 \times 4$ Latin square design with $27 \mathrm{~d}$ periods and a $2 \times 2$ factorial arrangement of treatments. Experimental periods consisted of $21 \mathrm{~d}$ of dietary adaptation and $6 \mathrm{~d}$ of data collection. Lambs were housed in individual floor pens (during dietary adaptation) or in metabolism crates (during data collection).

\section{Experimental treatments and feeding management}

The treatment factors were (1) $0(-\mathrm{SFO}) v .6 \%(+\mathrm{SFO}) \mathrm{SFO}$ (on a DM basis) as a defaunating agent and (2) DRB $v$. PB as the principal source of RFC. The ingredient and chemical compositions of the experimental diets containing DRB or $\mathrm{PB}$ are presented in Table 1 . The experimental diets were formulated to be isonitrogenous at $16 \mathrm{~g} \mathrm{~N} / \mathrm{kg} \mathrm{DM}$. The preparation of DRB and $\mathrm{PB}$ was as described by Kiran \& Mutsvangwa $^{(15)}$. DRB or PB was fed as the principal sources of dietary $\mathrm{RFC}$ in order to manipulate ruminal energy availability for microbial growth. Diets were offered in the form of a meal for ad libitum intake twice daily in equal portions at 09.00 and 17.00 hours, ensuring that $10 \%$ orts remained each day. Lambs had free access to water.

\section{Partial defaunation and refaunation}

Linoleic acid-rich SFO (Safeway ${ }^{\mathrm{TM}}$ Canada, Saskatoon, SK, Canada) was fed $(60 \mathrm{~g} / \mathrm{kg} \mathrm{DM})$ as an anti-protozoal agent. The protocol for ruminal defaunation was based on a previous study $^{(17)}$ and similar to Kiran \& Mutsvangwa ${ }^{(2)}$. The measured fatty acid composition of SFO was $6 \cdot 24,3 \cdot 87,26 \cdot 15,67 \cdot 07$ and $0.49 \%$ of palmitic $(16: 0)$, stearic $(18: 0)$, oleic $(18: 1)$, linoleic $(18: 2 n-6)$ and linolenic $(18: 3 n-3)$ acids, respectively.

Table 1. Ingredient and chemical composition of the experimental diets

\begin{tabular}{lcc}
\hline Item & $\begin{array}{c}\text { Dry-rolled } \\
\text { barley }\end{array}$ & $\begin{array}{c}\text { Pelleted } \\
\text { barley }\end{array}$ \\
\hline Ingredients (g/kg DM) & & \\
Alfalfa meal & 60 & 60 \\
Barley (dry-rolled) & 450 & - \\
Barley (pelleted) & - & 450 \\
Rapeseed meal & 20 & 20 \\
Maize gluten meal & 5 & 5 \\
Oat hulls & 350 & 350 \\
Soyabean meal & 15 & 15 \\
Rapeseed oil & 10 & 10 \\
Liquid molasses & 20 & 20 \\
Ground limestone & 40 & 40 \\
Salt, Co-I* & 7 & 7 \\
Salt white & 13 & 13 \\
Mineral-vitamin supplement† & 10 & 10 \\
Chemical composition & & \\
DM (g/kg) & 938 & 931 \\
Organic matter (g/kg DM) & 912 & 909 \\
Crude protein (g/kg DM) & $99 \cdot 2$ & $99 \cdot 9$ \\
Ruminally degradable protein $\ddagger$ & 636 & 636 \\
(g/kg crude protein) & & \\
Neutral-detergent fibre (g/kg DM) & 404 & 397 \\
Acid-detergent fibre (g/kg DM) & 207 & 209 \\
Ether extract (g/kg DM) & 36 & 37 \\
Metabolisable energy $¥$ (MJ/kg) & $7 \cdot 1$ & $7 \cdot 1$ \\
\hline
\end{tabular}

*Salt, Co and I mix: Co, $100 \mathrm{mg} / \mathrm{kg} ; \mathrm{I}, 150 \mathrm{mg} / \mathrm{kg}$.

†Provided (per kg of concentrate DM): CuO, 3.3 mg; ZnO, $22 \mathrm{mg} ; \mathrm{MnO}, 18.5 \mathrm{mg}$; vitamin A, $1495 \mathrm{IU}(0.449 \mathrm{mg})$; vitamin D, $125.5 \mathrm{IU}(0.0031 \mathrm{mg})$; vitamin E, $22 \mathrm{IU}$ $(20 \mathrm{mg})$; sodium selenite, $0.1 \mathrm{mg}$

$\ddagger$ Calculated according to the National Research Council ${ }^{(60)}$ guidelines. 
For lambs receiving SFO, daily allotments were calculated based on the previous day's DM intake. To avoid cross-inoculation of + SFO lambs by - SFO lambs via direct physical contact, individual floor pens and metabolism crates housing + SFO lambs were spaced several metres away from those housing - SFO lambs. In addition, ruminal fluid sampling of + SFO lambs was conducted before - SFO lambs in order to minimise the risk of cross-inoculation. To enumerate protozoa, $200 \mathrm{ml}$ of ruminal contents were sampled at 11.00 hours on day 1 to $3,6,9,12,15,18$ and 21-26. The processing of ruminal contents for protozoal counting was conducted as described by Kiran \& Mutsvangwa ${ }^{(2)}$, and protozoal enumeration and differentiation into different genera (i.e. Entodinium sp., holotrichs and cellulolytic protozoa) were conducted as described by Ogimoto \& Imai ${ }^{(18)}$. Partially defaunated lambs were refaunated at the start of an experimental period as described previously ${ }^{(2)}$.

\section{Sample collection}

Experimental lambs were moved from individual floor pens into individual metabolism crates on day 19 of each experimental period to allow acclimatisation before the initiation of data collection on day 22. During the $6 \mathrm{~d}$ data collection period, individual lamb feed intake was recorded daily. Samples of the experimental diets and orts were collected daily, stored at $-20^{\circ} \mathrm{C}$ and composited per lamb for each experimental period before chemical analysis. On day 21 of each experimental period, lambs were fitted with temporary vinyl catheters $(0.86 \mathrm{~mm}$ internal diameter $\times 1.32 \mathrm{~mm}$ outer diameter; Scientific Commodities, Inc., Lake Havasu City, AZ, USA) in the right and left jugular veins to allow for simultaneous isotope infusion and blood sampling. Urea-N transfer to the GIT and whole-body $\mathrm{N}$ balance were determined between days 22 and 26 as described by Lobley et al. ${ }^{(19)}$. Briefly, background samples of urine and faeces were collected on day 21 to measure the natural abundance of ${ }^{15} \mathrm{~N}$. Starting on day 22 of each experimental period, $\left[{ }^{15} \mathrm{~N}^{15} \mathrm{~N}\right]$ urea (99 atom $\%{ }^{15} \mathrm{~N}$; Cambridge Isotope Laboratories, Andover, MA, USA) prepared in $0.15 \mathrm{M}$-sterile saline was infused continuously into a jugular vein using a peristaltic pump for $96 \mathrm{~h}$. Daily dosage rates of $\left[{ }^{15} \mathrm{~N}^{15} \mathrm{~N}\right]$ urea ranged from 324 to $582 \mathrm{mg}$ /lamb depending on $\mathrm{N}$ intake, such that the predicted plateau enrichment of $\left[{ }^{15} \mathrm{~N}^{15} \mathrm{~N}\right]$ urea in urine was $0 \cdot 15 \mathrm{~mol} \%$ excess. Total faeces and urine were collected daily between days 22 and 26 before the 09.00 hours feeding to determine daily outputs. Collection, processing and sampling of faeces and urine for $\mathrm{N}$, and analysis of faecal ${ }^{15} \mathrm{~N}$ enrichment, urinary enrichment of $\left[{ }^{15} \mathrm{~N}^{15} \mathrm{~N}\right]-, \quad\left[{ }^{14} \mathrm{~N}^{15} \mathrm{~N}\right]-$ and $\left[{ }^{14} \mathrm{~N}^{14} \mathrm{~N}\right]$ urea and urinary purine derivatives (PD) were as described previously ${ }^{(2)}$.

On day 26, $200 \mathrm{ml}$ of ruminal contents were sampled at $09.00,11.00,13.00,15.00$ and 17.00 hours and squeezed through two layers of cheesecloth. Ruminal $\mathrm{pH}$ was immediately determined and $10 \mathrm{ml}$ aliquots of ruminal fluid were preserved as described previously ${ }^{(2)}$ for $\mathrm{NH}_{3}-\mathrm{N}$ and volatile fatty acid (VFA) analysis. The remaining ruminal fluid was kept frozen at $-20^{\circ} \mathrm{C}$ for the isolation of ruminal microbes.
At the same time points corresponding to ruminal fluid sampling, blood samples were drawn from a jugular vein catheter into vacutainers containing heparin, and plasma was obtained as described previously ${ }^{(2)}$ for plasma urea-N (PUN) analysis. On day 27, ruminal epithelial tissue biopsies were taken by clipping at $2 \mathrm{~h}$ after the morning feeding as described previously ${ }^{(2)}$.

Ruminal starch degradation in diets containing DRB and PB was determined using the in situ method as described by $\mathrm{Yu}$ et al. ${ }^{(20)}$. Briefly, approximately $7 \mathrm{~g}$ of each diet were weighed into nylon bags and incubated in the rumen of a dairy cow fed barley silage for 2, 4, 6, 8, 12, 24 and $48 \mathrm{~h}$. The rumen incubation protocol, nylon bags, washing and drying procedures for nylon bags were as described by Yu et al. ${ }^{(20)}$. Dried samples of the diet and nylon bag residues were analysed later for starch.

\section{Sample analyses}

At the end of the trial, frozen samples of the experimental diets, orts and faeces were thawed overnight at room temperature and analysed for DM by drying in an oven at $60^{\circ} \mathrm{C}$ for $48 \mathrm{~h}$ (method 930.15) ${ }^{(21)}$. Dried diets, orts and faeces were then ground through a $1 \mathrm{~mm}$ screen using a Christy-Norris mill (Christy and Norris Limited, Chelmsford, Essex, UK). Ground diets, orts and faecal samples were pooled per lamb and analysed for organic matter (OM) (method 942.05), $\mathrm{N}$ using the macro-Kjeldahl procedure (method 2001.11), total starch (method 996.11) using a commercial kit (Total Starch Assay Kit; Megazyme International Ireland Limited, Wicklow, Republic of Ireland), diethyl ether extract (method 2003.05) ${ }^{(21)}$, and acid-detergent fibre and neutral-detergent fibre ${ }^{(22)}$. Amylase and sodium sulphite were used for neutral-detergent fibre determination. Total $\mathrm{N}$ in pooled urine was determined using the macro-Kjeldahl procedure ${ }^{(21)}$. Dried nylon bag residues were analysed for total starch (method 996.11) using a commercial kit. The fatty acid composition of SFO was determined using GC (Agilent 6890; Agilent Technologies, Mississauga, ON, Canada) as described by Soita et al. ${ }^{(23)}$.

Preserved ruminal fluid samples were analysed for VFA by GC, as described by Erwin et al. ${ }^{(24)}$, and $\mathrm{NH}_{3}-\mathrm{N}$ using a phenol-hypochlorite assay ${ }^{(25)}$. Frozen ruminal fluid samples for microbial isolation were thawed at room temperature and centrifuged at $20000 \mathrm{~g}$ at $4^{\circ} \mathrm{C}$ for $20 \mathrm{~min}$, and the supernatant fraction was discarded. The microbial pellet was washed with double-distilled water and centrifuged at $20000 \mathrm{~g}$ at $4^{\circ} \mathrm{C}$ for $20 \mathrm{~min}$, and this process was repeated two more times ${ }^{(26)}$. The microbial pellet was then freezedried, ground with a mortar and pestle and analysed for total $\mathrm{N}$ and individual purines as described by Makkar \& Becker $^{(26)}$. Daily urine samples $(2 \mathrm{ml})$ that were diluted with distilled water $(8 \mathrm{ml})$ were pooled per lamb proportionally to daily urine output and analysed for allantoin, xanthine plus hypoxanthine ${ }^{(27)}$ and uric acid by a quantitative enzymatic colorimetric method using a commercial assay kit (Stanbio Uric Acid Liquicolor Kit, Procedure No. 1045; Stanbio Laboratories, Boerne, TX, USA). Total PD excretion/ $\mathrm{d}$ was calculated as allantoin + uric acid + xanthine plus 
hypoxanthine. Microbial non- $\mathrm{NH}_{3}-\mathrm{N}$ (NAN) supply was calculated based on total PD excretion in urine ${ }^{(27)}$, using the determined purine $\mathrm{N}$ :microbial $\mathrm{N}$ ratios and body-weight measurements obtained on day 19. PUN and urinary urea-N were determined by the diacetyl monoxime method ${ }^{(28)}$ using a commercial kit (Stanbio Urea N Kit, Procedure No. 0580; Stanbio Laboratories).

To determine the proportions of $\left[{ }^{15} \mathrm{~N}^{15} \mathrm{~N}\right]-,\left[{ }^{14} \mathrm{~N}^{15} \mathrm{~N}\right]-$ and $\left[{ }^{14} \mathrm{~N}^{14} \mathrm{~N}\right]$ urea in daily urine and background urine samples, urinary urea was isolated by applying urine containing $1.5 \mathrm{mg}$ of urea-N through pre-packed cation exchange resin columns (AG-50W- $\times 8$ Resin, 100-200 mesh, $\mathrm{H}^{+}$form; Biorad, Richmond, CA, USA) as described by Archibeque et $a l .{ }^{(29)}$. The proportions of $\left[{ }^{15} \mathrm{~N}^{15} \mathrm{~N}\right]-, \quad\left[{ }^{14} \mathrm{~N}^{15} \mathrm{~N}\right]-$ and $\left[{ }^{14} \mathrm{~N}^{14} \mathrm{~N}\right]$ urea in isolated urinary urea-N were analysed by isotope ratio-MS ${ }^{(19)}$ at the $\mathrm{N}-15$ Analysis Laboratory, University of Illinois at Urbana-Champaign. Under the conditions of this assay, $\left[{ }^{14} \mathrm{~N}^{14} \mathrm{~N}\right]-,\left[{ }^{14} \mathrm{~N}^{15} \mathrm{~N}\right]-$ and $\left[{ }^{15} \mathrm{~N}^{15} \mathrm{~N}\right]$ urea molecules should yield ions with mass/charge values of 28, 29 and 30, respectively. To account for non-monomolecular reactions, standards that were prepared from $\left[{ }^{15} \mathrm{~N}^{15} \mathrm{~N}\right]$ urea (99.8 atom $\%{ }^{15} \mathrm{~N}$ ) and $\left[{ }^{14} \mathrm{~N}^{14} \mathrm{~N}\right]$ urea (natural abundance urea; 0.364 atom $\%{ }^{15} \mathrm{~N}$ ) were also analysed, and the necessary corrections for $\left[{ }^{14} \mathrm{~N}^{15} \mathrm{~N}\right]$ urea that was produced by non-monomolecular reactions were then made ${ }^{(19)}$. Faecal samples were analysed for total ${ }^{15} \mathrm{~N}$ enrichment by combustion to $\mathrm{N}_{2}$ gas in an elemental analyser and continuous flow isotope ratio-MS ${ }^{(19)}$. For urea transporter-B (UT-B) gene expression analysis, processing of ruminal epithelial tissue, RNA extraction, complementary DNA generation and quantification of gene transcript abundance using quantitative PCR were conducted as described previously ${ }^{(2)}$. Ovine-glyceraldehyde 3-phosphate dehydrogenase was used as an internal reference to UT-B mRNA expression. The results are presented as target gene transcript abundance normalised to glyceraldehyde 3-phosphate dehydrogenase transcript abundance. Expression of glyceraldehyde 3-phosphate dehydrogenase mRNA in equal amounts of total RNA indicated that glyceraldehyde 3-phosphate dehydrogenase in rumen epithelial tissue was stable and unaffected by the experimental conditions that were employed.

\section{Calculation of urea-nitrogen kinetics and statistical analysis}

Rumen degradation characteristics of starch were analysed using the non-linear regression (NLIN) procedure ${ }^{(30)}$ using iterative least-squares regression (Gauss-Newton method) as described by $\mathrm{Yu}$ et $a{ }^{(20)}$. Urea-N kinetics was calculated according to the model of Lobley et al. ${ }^{(19)}$, using urinary ${ }^{15} \mathrm{~N}$ enrichment of $\left[{ }^{15} \mathrm{~N}^{15} \mathrm{~N}\right]$ - and $\left[{ }^{14} \mathrm{~N}^{15} \mathrm{~N}\right]$ urea and total ${ }^{15} \mathrm{~N}$ excretion in faeces. All data were analysed using ANOVA as a $4 \times 4$ Latin square using the Proc Mixed procedure of SAS ${ }^{(30)}$, with animal and period as the random effects. The model used included the following independent variables: animal, period, SFO $(-\mathrm{SFO} v++\mathrm{SFO})$, barley grain processing (DRB $v . \mathrm{PB})$ and the $\mathrm{SFO} \times$ barley grain processing interaction. When significant $\mathrm{SFO} \times$ barley grain processing interactions were detected, treatment means were compared using the Tukey-Kramer multiple comparison test. Data on PUN, ruminal $\mathrm{pH}$ and ruminal concentrations of VFA and $\mathrm{NH}_{3}-\mathrm{N}$ were analysed accounting for repeated measures ${ }^{(31)}$. For protozoal counts, statistical analysis was performed on log-transformed data. Treatment differences were considered significant when $P<0.05$ and tendencies are discussed when $0.05<P<0.10$. Data are presented as means with their standard errors.

\section{Results}

In situ ruminal starch degradation kinetics

In situ ruminal starch degradation kinetics is presented in Table 2. The in situ soluble and degradable starch fractions, the degradation rate of the degradable starch fraction and the effective starch degradability were greater $(P \leq 0.02)$ in the diet that contained $\mathrm{PB}$ when compared with that containing DRB.

\section{DM intake and total tract nutrient digestibilities}

$\mathrm{DM}$ and $\mathrm{OM}$ intakes were unaffected $(P \geq 0 \cdot 14)$ by treatment (Table 3). Total tract digestibilities of DM, OM, N, aciddetergent fibre and neutral-detergent fibre were unaffected $(P \geq 0 \cdot 24)$ by feeding SFO and by the method of barley grain processing. Total tract digestibility of starch was greater $(P=0.001)$ in lambs fed PB compared with those fed DRB, but was unaffected by feeding SFO.

\section{Ruminal protozoal counts and fermentation characteristics}

Treatment means for ruminal counts of protozoa during the measurement period (days 22-27) are presented in Table 4. Ruminal counts of total protozoa, Entodinium sp., holotrichs and cellulolytic protozoa were greater in -SFO lambs fed DRB compared with those fed PB $(P<0 \cdot 01)$; consequently, there was a greater difference in ruminal counts of total protozoa, Entodinium sp., holotrichs and cellulolytic protozoa between $-\mathrm{SFO}$ and + SFO lambs fed DRB compared with those fed PB (interaction; $P<0 \cdot 01$ ). Experimental lambs were successfully refaunated by the administration of the ruminal fluid from naturally faunated sheep over $3 \mathrm{~d}$, and mean populations $(n$ ) for total protozoa $(10 \cdot 6$ (SE $\left.0 \cdot 3) \times 10^{5} / \mathrm{ml}\right)$, Entodinium sp. $\left(10 \cdot 2 \quad(\mathrm{sE} \quad 0 \cdot 3) \times 10^{5} / \mathrm{ml}\right)$,

Table 2. In situ ruminal degradation kinetics of starch in experimental diets containing dry-rolled barley or pelleted barley

(Mean values with their standard errors)

\begin{tabular}{lcccc}
\hline Item & $\begin{array}{c}\text { Dry-rolled } \\
\text { barley }\end{array}$ & $\begin{array}{c}\text { Pelleted } \\
\text { barley }\end{array}$ & SEM & $P$ \\
\hline Soluble fraction (\%) & 9.5 & 15.1 & 0.72 & 0.002 \\
Degradable fraction (\%) & 79.6 & 81.0 & 0.35 & 0.02 \\
Degradation rate (\%/h) & 13.7 & 16.4 & 0.56 & 0.009 \\
Effective degradability* (\%) & 65.2 & 74.5 & 0.92 & 0.001 \\
\hline
\end{tabular}

${ }^{\star}$ Calculated assuming a ruminal passage rate of $6 \% / \mathrm{h}$. 
Table 3. Sunflower oil (SFO), basal DM, total organic matter (OM) intakes, and total tract nutrient digestibility in lambs fed dry-rolled or pelleted barley with $(+\mathrm{SFO})$ or without $(-\mathrm{SFO})$ SFO as a partial defaunating agent (Mean values with their standard errors, $n 4$ )

\begin{tabular}{|c|c|c|c|c|c|c|c|c|}
\hline \multirow[b]{2}{*}{ Item } & \multicolumn{2}{|c|}{ Dry-rolled barley } & \multicolumn{2}{|c|}{ Pelleted barley } & \multirow[b]{2}{*}{ SEM } & \multicolumn{3}{|c|}{$P^{*}$} \\
\hline & $-\mathrm{SFO}$ & + SFO & $-\mathrm{SFO}$ & + SFO & & SFO & BP & $\mathrm{SFO} \times \mathrm{BP}$ \\
\hline \multicolumn{9}{|l|}{ Intakes (g/d) } \\
\hline SFO & - & $118 \cdot 2$ & - & 108.5 & - & - & - & - \\
\hline Basal DM† & 2074 & 1970 & 1856 & 1809 & 119.6 & 0.54 & 0.14 & 0.82 \\
\hline Total OM $\ddagger$ & 1901 & 2039 & 1701 & 1872 & $115 \cdot 9$ & 0.21 & 0.14 & 0.88 \\
\hline \multicolumn{9}{|c|}{ Nutrient digestibility (\%) } \\
\hline DM & $62 \cdot 4$ & 57.9 & 60.9 & 62.4 & $2 \cdot 4$ & 0.55 & 0.54 & 0.24 \\
\hline OM & $65 \cdot 2$ & 63.9 & 63.7 & $67 \cdot 8$ & $2 \cdot 1$ & 0.51 & 0.59 & 0.22 \\
\hline Starch & $88 \cdot 6$ & 87.8 & $96 \cdot 6$ & $97 \cdot 3$ & 1.8 & 0.94 & 0.001 & 0.38 \\
\hline $\mathrm{N}$ & $75 \cdot 7$ & $72 \cdot 0$ & $73 \cdot 3$ & $75 \cdot 3$ & 2.8 & 0.77 & 0.86 & 0.33 \\
\hline ADF & $30 \cdot 6$ & $26 \cdot 0$ & $30 \cdot 0$ & 28.6 & 5.6 & 0.60 & 0.86 & 0.79 \\
\hline NDF & $32 \cdot 2$ & 28.9 & 28.5 & $28 \cdot 1$ & $5 \cdot 6$ & 0.74 & 0.70 & 0.79 \\
\hline
\end{tabular}

$\mathrm{BP}$, barley grain processing; ADF, acid-detergent fibre; NDF, neutral-detergent fibre.

* SFO, addition of $6 \%$ (DM basis) of linoleic acid-rich sunflower oil as a partial defaunating agent; BP, dry-rolled $v$. pelleted $\mathrm{SFO} \times \mathrm{BP}$, interaction.

†Basal DM intake does not include SFO intake.

$\ddagger$ Total OM intake includes SFO intake.

holotrichs $\left(0 \cdot 24(\mathrm{se} 0 \cdot 02) \times 10^{5} / \mathrm{ml}\right)$ and cellulolytic protozoa $\left(0.20(\right.$ SE 0.02$\left.) \times 10^{5} / \mathrm{ml}\right)$ were restored to pre-defaunation levels in previously partially defaunated lambs by day 15 of the experimental period.

For ruminal $\mathrm{pH}$ and $\mathrm{NH}_{3}-\mathrm{N}$ and VFA concentrations, sampling time $\times$ barley grain processing $\times$ ruminal protozoal status interactions were minor, so treatment means are presented (Table 4). Ruminal $\mathrm{pH}$ was higher $(P=0.001)$ in + SFO lambs compared with - SFO lambs. Ruminal $\mathrm{pH}$ was lower $(P=0.02)$ in lambs fed PB compared with those fed DRB. Ruminal $\mathrm{NH}_{3}-\mathrm{N}$ concentration was lower $(P=0 \cdot 001)$ in + SFO lambs compared with - SFO lambs, and the difference in the ruminal $\mathrm{NH}_{3}-\mathrm{N}$ concentration between $+\mathrm{SFO}$ and - SFO lambs was greater with DRB than with PB (interaction; $P<0 \cdot 01)$. Ruminal concentrations of total VFA, acetate and butyrate were lower $(P=0 \cdot 001)$, whereas those of propionate were higher $(P=0.001)$ in + SFO lambs compared with $-\mathrm{SFO}$ lambs; consequently, the acetate:propionate ratio was lower $(P=0 \cdot 001)$ in + SFO lambs compared with - SFO lambs. Ruminal concentrations of total and individual VFA were similar in lambs fed either DRB or PB, except for a higher $(P=0.001)$ ruminal concentration of valerate and a lower $(P=0.009)$ acetate:propionate ratio in lambs fed $\mathrm{PB}$ compared with those fed DRB.

Table 4. Ruminal fermentation characteristics and protozoa number in lambs fed dry-rolled or pelleted barley with (+SFO) or without (-SFO) sunflower oil (SFO) as a partial defaunating agent

(Mean values with their standard errors, $n 4$ )

\begin{tabular}{|c|c|c|c|c|c|c|c|c|}
\hline \multirow[b]{2}{*}{ Item } & \multicolumn{2}{|c|}{ Dry-rolled barley } & \multicolumn{2}{|c|}{ Pelleted barley } & \multirow[b]{2}{*}{ SEM } & \multicolumn{3}{|c|}{$P^{*}$} \\
\hline & $-\mathrm{SFO}$ & $+\mathrm{SFO}$ & $-\mathrm{SFO}$ & + SFO & & SFO & $\mathrm{BP}$ & $\mathrm{SFO} \times \mathrm{BP}$ \\
\hline \multicolumn{9}{|l|}{ Protozoa $\left(\times 10^{5} / \mathrm{ml}\right) \dagger$} \\
\hline Entodinium sp. & $10 \cdot 2^{\mathrm{a}}$ & $1 \cdot 3^{b}$ & $6 \cdot 2^{\mathrm{c}}$ & ND & 0.25 & 0.001 & 0.001 & 0.001 \\
\hline Holotrichs & $0.28^{a}$ & $0.01^{\mathrm{b}}$ & $0.16^{\mathrm{c}}$ & ND & 0.02 & 0.001 & 0.007 & 0.008 \\
\hline Cellulolytics $\ddagger$ & $0.20^{\mathrm{a}}$ & ND & $0.09^{c}$ & ND & 0.02 & 0.001 & 0.003 & 0.003 \\
\hline Total & $10 \cdot 7^{\mathrm{a}}$ & $1 \cdot 3^{\mathrm{b}}$ & $6 \cdot 4^{\mathrm{c}}$ & ND & 0.27 & 0.001 & 0.001 & 0.001 \\
\hline $\mathrm{pH}$ & $5 \cdot 8$ & $6 \cdot 2$ & $5 \cdot 7$ & $6 \cdot 0$ & 0.05 & 0.001 & 0.02 & 0.86 \\
\hline $\mathrm{NH}_{3}-\mathrm{N}(\mathrm{mmol} / \mathrm{l})$ & $5 \cdot 7^{\mathrm{a}}$ & $3.5^{\mathrm{b}}$ & $4 \cdot 5^{\mathrm{c}}$ & $3 \cdot 3^{\mathrm{b}}$ & 0.13 & 0.001 & 0.001 & 0.002 \\
\hline \multicolumn{9}{|l|}{ VFA concentration $(\mathrm{mmol} / \mathrm{l})$} \\
\hline Total & $100 \cdot 3$ & $92 \cdot 8$ & $98 \cdot 2$ & $94 \cdot 1$ & $1 \cdot 13$ & 0.001 & 0.72 & 0.15 \\
\hline Acetate & $62 \cdot 1$ & 55.4 & 59.2 & $55 \cdot 3$ & 1.08 & 0.001 & 0.19 & 0.22 \\
\hline Propionate & $18 \cdot 5$ & 21.5 & $19 \cdot 3$ & $22 \cdot 3$ & 0.48 & 0.001 & 0.13 & 0.99 \\
\hline Butyrate & $16 \cdot 3$ & 11.5 & $15 \cdot 9$ & $12 \cdot 6$ & 0.55 & 0.001 & 0.55 & 0.24 \\
\hline Isobutyrate & 0.79 & 0.71 & 0.83 & 0.72 & 0.07 & 0.18 & 0.73 & 0.84 \\
\hline Valerate & $1 \cdot 3$ & 1.4 & 1.6 & $1 \cdot 6$ & 0.06 & 0.26 & 0.01 & 0.32 \\
\hline Isovalerate & $1 \cdot 2$ & 1.4 & 1.4 & 1.7 & 0.29 & 0.09 & 0.36 & 0.32 \\
\hline Acetate:propionate ratio & 3.4 & $2 \cdot 6$ & $3 \cdot 1$ & 2.5 & 0.06 & 0.001 & 0.009 & 0.17 \\
\hline
\end{tabular}

$\mathrm{BP}$, barley grain processing; ND, not detectable; VFA, volatile fatty acid.

a,b,c Mean values within a row with unlike superscript letters were significantly different $(P<0.05)$.

${ }^{*}$ SFO, addition of $6 \%$ (DM basis) of linoleic acid-rich sunflower oil as a partial defaunating agent; BP, dry-rolled $v$. pelleted; SFO $\times$ BP, interaction. $\dagger$ Treatment means for ruminal counts of protozoa during the measurement period (days 22-27).

$\ddagger$ Includes Polyplastron, Diplodinium and Enoplastron spp. 


\section{Nitrogen balance and plasma urea-nitrogen concentration}

Intakes of $\mathrm{N}$ were similar across treatments (Table 5). Faecal N excretion was unaffected by treatment. Urinary excretion of total $\mathrm{N}$ was $2.7-4.9 \mathrm{~g} / \mathrm{d}$ less $(P=0.003)$ in + SFO lambs compared with $-\mathrm{SFO}$ lambs; consequently, total $\mathrm{N}$ excretion, when expressed as absolute amounts $(P=0 \cdot 02)$ or as a proportion of $\mathrm{N}$ intake $(P=0 \cdot 001)$, was lower, and $\mathrm{N}$ retention, when expressed as absolute amounts $(P=0.002)$ or as a proportion of $\mathrm{N}$ intake $(P=0 \cdot 001)$, was higher in + SFO lambs compared with - SFO lambs. Lambs fed PB excreted 2.5$4.7 \mathrm{~g} / \mathrm{d}$ less $(P=0.004)$ urinary $\mathrm{N}$ compared with those fed DRB. Total $\mathrm{N}$ loss, when expressed in absolute amounts $(P=0.01)$ or as a proportion of $\mathrm{N}$ intake $(P=0.001)$, was lower in lambs fed PB compared with those fed DRB. Consequently, $\mathrm{N}$ retention when expressed in absolute amounts tended to be greater $(P=0.09)$ or when expressed as a proportion of $\mathrm{N}$ intake was greater $(P=0.001)$ in lambs fed $\mathrm{PB}$ compared with those fed DRB. The PUN concentration was greater $(P=0.001)$ in $-\mathrm{SFO}$ lambs compared with $+\mathrm{SFO}$ lambs, but the method of barley grain processing had no effect on PUN concentration.

\section{Urea-nitrogen kinetics, mRNA abundance of urea} transporter-B and microbial non-ammonia nitrogen supply

Across treatments, urinary $\left[{ }^{15} \mathrm{~N}^{15} \mathrm{~N}\right]$ urea enrichment reached a plateau within $24-48 \mathrm{~h}$ of isotopic infusion, whereas plateau enrichment of $\left[{ }^{14} \mathrm{~N}^{15} \mathrm{~N}\right]$ urea in urine was not attained until between 48 and $72 \mathrm{~h}$ of isotopic infusion (data not shown). Faecal ${ }^{15} \mathrm{~N}$ enrichments increased daily over the $4 \mathrm{~d}$ isotopic infusion without attaining a definite plateau (data not shown); therefore, for calculations of urea-N kinetics, faecal ${ }^{15} \mathrm{~N}$ enrichments over the final $72-96 \mathrm{~h}$ of infusion were used.
Only minor interactions on urea-N kinetics were detected between feeding SFO and the method of barley grain processing (Table 6) . Endogenous urea-N production (i.e. urea-N entry rate; UER) was similar in $-\mathrm{SFO}$ and $+\mathrm{SFO}$ lambs $(P=0 \cdot 48)$. The urea-N gastrointestinal entry rate (i.e. GER), when expressed in absolute amounts $(P=0.008)$ or as a proportion of UER (i.e. UER to GIT; $P=0 \cdot 001$ ), was greater in + SFO lambs compared with - SFO lambs. The urea-N that was used for anabolic purposes (i.e. UUA), when expressed in absolute amounts $(P=0.008)$ or as a proportion of GER (i.e. GER to UUA; $P=0 \cdot 04$ ), was higher in + SFO lambs compared with - SFO lambs. Conversely, the amount of UER that was lost in urine, when expressed in absolute amounts $(P=0.001)$ or as a proportion of UER (i.e. UER to urine; $P=0.001)$, was lower in + SFO lambs compared with $-\mathrm{SFO}$ lambs. The urea- $\mathrm{N}$ that re-entered the ornithine cycle (i.e. ROC) was unaffected by feeding SFO; however, when expressed as a proportion of GER (i.e. GER to ROC), there was a tendency $(P=0.08)$ for it to be lower in + SFO lambs compared with $-\mathrm{SFO}$ lambs. The urea-N to faecal excretion (i.e. UFE) was unaffected by feeding SFO. UER, GER, UUA, UFE and ROC were similar in lambs fed DRB or PB. The urinary urea-N elimination, when expressed in absolute amounts $(P=0.001)$ or as a proportion of UER $(P=0.01)$, was lower, whereas GER when expressed as a proportion of UER was higher $(P=0 \cdot 01)$, in lambs fed PB compared with those fed DRB. The expression of UT-B mRNA was unaffected by treatment.

Urinary excretion of allantoin and total PD was higher ( $P=0 \cdot 001)$ and, correspondingly, microbial NAN supply estimated using urinary PD excretion and measured purine $\mathrm{N}$ :microbial $\mathrm{N}$ ratios was higher $(P=0 \cdot 001)$ in $+\mathrm{SFO}$ lambs compared with - SFO lambs (Table 7). Compared with lambs fed DRB, those fed PB excreted more allantoin

Table 5. Nitrogen intake, nitrogen balance and plasma urea-nitrogen in lambs fed dry-rolled or pelleted barley with (+SFO) or without (-SFO) sunflower oil (SFO) as a partial defaunating agent

(Mean values with their standard errors, $n 4$ )

\begin{tabular}{|c|c|c|c|c|c|c|c|c|}
\hline \multirow[b]{2}{*}{ Item } & \multicolumn{2}{|c|}{ Dry-rolled barley } & \multicolumn{2}{|c|}{ Pelleted barley } & \multirow[b]{2}{*}{ SEM } & \multicolumn{3}{|c|}{$P^{*}$} \\
\hline & $-\mathrm{SFO}$ & $+\mathrm{SFO}$ & $-\mathrm{SFO}$ & $+\mathrm{SFO}$ & & SFO & $\mathrm{BP}$ & $\mathrm{SFO} \times \mathrm{BP}$ \\
\hline$N$ intake $(g / d)$ & $33 \cdot 7$ & 31.9 & $29 \cdot 9$ & $29 \cdot 1$ & 1.9 & 0.52 & 0.12 & 0.80 \\
\hline \multicolumn{9}{|l|}{ Faecal $\mathrm{N}$ excretion } \\
\hline $\mathrm{g} / \mathrm{d}$ & $8 \cdot 1$ & $9 \cdot 0$ & $8 \cdot 2$ & $7 \cdot 2$ & $1 \cdot 2$ & 0.97 & 0.49 & 0.46 \\
\hline Total N excretion (\%) & 31.6 & $41 \cdot 0$ & 37.5 & 40.9 & 3.8 & 0.10 & 0.45 & 0.44 \\
\hline \multicolumn{9}{|l|}{ Urine $\mathrm{N}$ excretion } \\
\hline \multicolumn{9}{|l|}{ Total $\mathrm{N}$} \\
\hline$g / d$ & $17 \cdot 7$ & $12 \cdot 8$ & $13 \cdot 0$ & $10 \cdot 3$ & 1.1 & 0.003 & 0.004 & 0.29 \\
\hline Total N excretion (\%) & $68 \cdot 4$ & 58.9 & 62.5 & $59 \cdot 1$ & 3.8 & 0.10 & 0.45 & 0.44 \\
\hline Urea-N $(\mathrm{g} / \mathrm{d})$ & $11 \cdot 2^{\mathrm{a}}$ & $7 \cdot 8^{\mathrm{b}}$ & $8 \cdot 4^{\mathrm{b}}$ & $6 \cdot 7^{\mathrm{C}}$ & 0.33 & 0.001 & 0.001 & 0.03 \\
\hline \multicolumn{9}{|l|}{ Total N excretion } \\
\hline $\mathrm{g} / \mathrm{d}$ & $25 \cdot 8$ & $21 \cdot 7$ & $21 \cdot 2$ & 17.5 & 1.5 & 0.02 & 0.01 & 0.88 \\
\hline $\mathrm{N}$ intake (\%) & $76 \cdot 8$ & 68.2 & 71.0 & $60 \cdot 2$ & 1.1 & 0.001 & 0.001 & 0.33 \\
\hline \multicolumn{9}{|l|}{$\mathrm{N}$ retention } \\
\hline$g / d$ & $7 \cdot 8$ & $10 \cdot 1$ & 8.7 & 11.6 & 0.65 & 0.002 & 0.09 & 0.66 \\
\hline $\mathrm{N}$ intake (\%) & $23 \cdot 2$ & 31.8 & $29 \cdot 0$ & 39.8 & 1.1 & 0.001 & 0.001 & 0.33 \\
\hline Plasma urea- $\mathrm{N}(\mathrm{mmol} / \mathrm{l})$ & 3.4 & 2.4 & $3 \cdot 1$ & $2 \cdot 4$ & 0.19 & 0.001 & 0.51 & 0.47 \\
\hline
\end{tabular}

$\mathrm{BP}$, barley grain processing

a,b,c Mean values within a row with unlike superscript letters were significantly different $(P<0.05)$.

* SFO, addition of $6 \%$ (DM basis) of linoleic acid-rich sunflower oil as a partial defaunating agent; BP, dry-rolled $v$. pelleted; SFO $\times$ BP, interaction. 
Table 6. Urea-nitrogen recycling kinetics, as measured using $4 \mathrm{~d}$ continuous intra-jugular infusions of $\left[{ }^{15} \mathrm{~N}^{15} \mathrm{~N}\right]$ urea, and urea transporter-B (UT-B) mRNA abundance in ruminal epithelial tissue in lambs fed dry-rolled or pelleted barley with (+SFO) or without ( $-\mathrm{SFO}$ ) sunflower oil (SFO) as a partial defaunating agent

(Mean values with their standard errors, $n 4$ )

\begin{tabular}{|c|c|c|c|c|c|c|c|c|}
\hline \multirow[b]{2}{*}{ Item } & \multicolumn{2}{|c|}{ Dry-rolled barley } & \multicolumn{2}{|c|}{ Pelleted barley } & \multirow[b]{2}{*}{ SEM } & \multicolumn{3}{|c|}{$P^{*}$} \\
\hline & $-\mathrm{SFO}$ & $+\mathrm{SFO}$ & $-\mathrm{SFO}$ & $+\mathrm{SFO}$ & & SFO & BP & $\mathrm{SFO} \times \mathrm{BP}$ \\
\hline \multicolumn{9}{|l|}{ Urea-N kinetics (g/d) } \\
\hline UER & 23.2 & $24 \cdot 6$ & 22.5 & $22 \cdot 6$ & 1.04 & 0.48 & 0.24 & 0.53 \\
\hline GER & $12 \cdot 0$ & $16 \cdot 8$ & $14 \cdot 1$ & $16 \cdot 0$ & 1.04 & 0.008 & 0.55 & 0.18 \\
\hline ROC & $5 \cdot 8$ & $6 \cdot 8$ & $6 \cdot 8$ & $6 \cdot 3$ & 0.60 & 0.67 & 0.69 & 0.22 \\
\hline UFE & 0.81 & 0.77 & 0.75 & 0.92 & $0 \cdot 10$ & 0.54 & 0.64 & 0.35 \\
\hline UUE & $11 \cdot 2^{\mathrm{a}}$ & $7 \cdot 8^{\mathrm{b}}$ & $8 \cdot 4^{b}$ & $6 \cdot 7^{\mathrm{c}}$ & 0.33 & 0.001 & 0.001 & 0.03 \\
\hline UUA & $5 \cdot 5$ & $9 \cdot 2$ & $6 \cdot 6$ & $8 \cdot 8$ & 0.92 & 0.008 & 0.71 & 0.41 \\
\hline \multicolumn{9}{|l|}{ Fractional urea- $\mathrm{N}$ transfers } \\
\hline UER to urine & 0.483 & 0.319 & 0.378 & 0.295 & 0.022 & 0.001 & 0.01 & 0.09 \\
\hline UER to GIT & 0.517 & 0.680 & 0.622 & 0.705 & 0.022 & 0.001 & 0.01 & 0.09 \\
\hline GER to ROC & 0.478 & 0.409 & 0.489 & 0.395 & 0.042 & 0.08 & 0.96 & 0.77 \\
\hline GER to faeces & 0.068 & 0.047 & 0.053 & 0.057 & 0.007 & 0.22 & 0.74 & 0.08 \\
\hline GER to UUA & 0.453 & 0.544 & 0.458 & 0.548 & 0.040 & 0.04 & 0.91 & 0.99 \\
\hline $\begin{array}{l}\text { UT-B mRNA abundance } \\
\text { (per copy of GAPDH) }\end{array}$ & $10 \cdot 5$ & $11 \cdot 3$ & $10 \cdot 3$ & $11 \cdot 0$ & 1.41 & 0.63 & $0 \cdot 84$ & 0.96 \\
\hline
\end{tabular}

$(P=0.02)$ and tended to excrete more xanthine plus hypoxanthine $(P=0 \cdot 06)$ and total PD $(P=0 \cdot 09)$; however, microbial NAN supply was unaffected $(P=0 \cdot 22)$ by barley grain processing.

\section{Discussion}

Feeding SFO to achieve partial defaunation in lambs had no impact on DM intake, which is in contrast to our previous study $^{(2)}$ in which we observed a decrease in DM intake when lambs were fed SFO. Lambs that were used in the present study were heavier $(+17 \mathrm{~kg})$ and older than those that were used in our initial study, and this could partly explain why responses in DM intake were different. As expected, based on previous studies in which SFO was used as a defaunating agent ${ }^{(2,17)}$, ruminal protozoal counts decreased substantially within $6 \mathrm{~d}$ after the initiation of feeding SFO.
Feeding PB also resulted in a decrease in ruminal protozoal counts when compared with DRB, supporting previous studies that have reported decreases in ruminal protozoal populations in ruminants fed extensively processed barley $^{(13,14)}$. The major changes that were observed in ruminal fermentation characteristics, i.e. a decrease in ruminal $\mathrm{NH}_{3}-\mathrm{N}$, total VFA, acetate and butyrate concentrations and an increase in ruminal propionate concentration, are typical of changes that are associated with partial or complete defaunation $^{(17,32,33)}$. Ruminal $\mathrm{pH}$ was higher in + SFO lambs compared with - SFO lambs, which is in agreement with other studies $^{(2,17,34)}$.

Total tract digestibilities of DM, OM, starch, N, aciddetergent fibre and neutral-detergent fibre were unaffected by feeding SFO to achieve partial defaunation, supporting previous findings $^{(2)}$. It appears that, because of the inhibition of protozoal activities in the rumen, most of the available data

Table 7. Urinary output, urinary purine derivative (PD) excretion and microbial non-ammonia nitrogen (NAN) supply in lambs fed dry-rolled or pelleted barley with (+SFO) or without (-SFO) sunflower oil (SFO) as a partial defaunating agent

(Mean values with their standard errors, $n 4)$

\begin{tabular}{|c|c|c|c|c|c|c|c|c|}
\hline \multirow[b]{2}{*}{ Item } & \multicolumn{2}{|c|}{ Dry-rolled barley } & \multicolumn{2}{|c|}{ Pelleted barley } & \multirow[b]{2}{*}{ SEM } & \multicolumn{3}{|c|}{$P^{*}$} \\
\hline & $-\mathrm{SFO}$ & + SFO & $-\mathrm{SFO}$ & + SFO & & SFO & $\mathrm{BP}$ & $\mathrm{SFO} \times \mathrm{BP}$ \\
\hline \multicolumn{9}{|l|}{ Urinary excretion } \\
\hline Total output (kg/d) & $2 \cdot 0$ & 1.9 & $1 \cdot 7$ & $1 \cdot 6$ & $0 \cdot 20$ & 0.66 & 0.16 & 0.82 \\
\hline Allantoin excretion (mmol/d) & $5 \cdot 9$ & $8 \cdot 6$ & $7 \cdot 1$ & 9.9 & 0.49 & 0.001 & 0.02 & 0.89 \\
\hline Uric acid excretion (mmol/d) & $1 \cdot 6$ & $2 \cdot 2$ & $2 \cdot 2$ & $2 \cdot 0$ & $0 \cdot 30$ & 0.53 & 0.57 & 0.22 \\
\hline Xanthine plus hypoxanthine $(\mathrm{mmol} / \mathrm{d})$ & $0.98^{\mathrm{a}, \mathrm{b}}$ & $1 \cdot 20^{a}$ & $0.99^{a, b}$ & $0.83^{b}$ & 0.09 & 0.76 & 0.06 & 0.04 \\
\hline Total PD excretion $(\mathrm{mmol} / \mathrm{d})$ & 8.5 & $12 \cdot 0$ & $10 \cdot 3$ & $12 \cdot 7$ & $0 \cdot 70$ & 0.001 & 0.09 & 0.48 \\
\hline Microbial NAN supply† (g/d) & $10 \cdot 0$ & $14 \cdot 1$ & $11 \cdot 8$ & $15 \cdot 0$ & 1.05 & 0.005 & 0.22 & 0.64 \\
\hline
\end{tabular}

$\mathrm{BP}$, barley grain processing; $\mathrm{PD}$, purine derivatives.

a,b Mean values within a row with unlike superscript letters were significantly different $(P<0.05)$.

* SFO, addition of $6 \%$ (DM basis) of linoleic acid-rich sunflower oil as a partial defaunating agent; BP, dry-rolled $v$. pelleted; SFO $\times$ BP, interaction.

† Microbial NAN supply was calculated according to Chen \& Gomes ${ }^{(27)}$, using determined purine N:microbial N ratios. 
when high-oil diets are fed to achieve partial or complete defaunation indicate a decrease in ruminal OM or fibre digestion $^{(35,36)}$. If ruminal fibre digestion was depressed by feeding SFO in the present study, this was compensated for postruminally as total tract digestibilities were not affected. Both in situ ruminal and total tract starch digestibility were greater with PB compared with DRB. In common with the present study, Yang et al. ${ }^{(37)}$ reported increases in ruminal and total tract starch digestion, as the extent of barley grain processing was increased in dairy cows fed barley-based diets. The present results suggest that the lower ruminal digestion of DRB (as reflected by the lower in situ degradation kinetics relative to PB) was not compensated for by greater intestinal digestion, which supports previous findings ${ }^{(37)}$.

In ruminants, protozoa impose inefficiencies in $\mathrm{N}$ utilisation at a number of different levels, and the eradication of ruminal protozoa typically improves $\mathrm{N}$ utilisation ${ }^{(4)}$. In the present study, - SFO and + SFO lambs had similar $\mathrm{N}$ intakes and faecal $\mathrm{N}$ losses; however, feeding SFO to partially defaunate the rumen decreased total $\mathrm{N}$ excretion by $3 \cdot 7-4 \cdot 1 \mathrm{~g} / \mathrm{d}$, with most of this decrease in total $\mathrm{N}$ excretion being accounted for by a decrease in urinary urea- $\mathrm{N}$ excretion. Consequently, + SFO lambs retained $2 \cdot 3-2 \cdot 9 \mathrm{~g} / \mathrm{d}$ more $\mathrm{N}$ when compared with - SFO lambs, thus suggesting a greater efficiency of $\mathrm{N}$ utilisation with defaunation as has been reported by others $^{(2,4)}$. This improved $\mathrm{N}$ utilisation in defaunated ruminants is accounted for by various mechanisms, including a decrease in the ruminal $\mathrm{NH}_{3}-\mathrm{N}$ pool, coupled with a greater sequestration of $\mathrm{NH}_{3}-\mathrm{N}$ into bacterial protein ${ }^{(3)}$, a decrease in intra-ruminal $\mathrm{N}$ recycling ${ }^{(4)}$ and an increase in microbial $\mathrm{N}$ flow to the duodenum by $20-60 \%{ }^{(4,32)}$. Besides the change in protozoal status, associated changes in energy supply and ruminal VFA patterns could also be partly responsible for improving the efficiency of post-absorptive $\mathrm{N}$ use in + SFO lambs. Assuming that the energy content of SFO is $36 \cdot 8 \mathrm{MJ} / \mathrm{kg}$, dietary supplementation with $6 \%$ SFO increased the energy intake of + SFO lambs by $3.98-4.35 \mathrm{MJ}$ of gross energy/d, and this additional energy intake could have influenced post-absorptive $\mathrm{N}$ use. In growing steers, increasing energy intake by abomasally infusing $150 \mathrm{~g} / \mathrm{d}$ of a mixture of fatty acids (equivalent to an additional $5.44 \mathrm{MJ}$ of gross energy/d) decreased urinary $\mathrm{N}$ excretion and increased $\mathrm{N}$ retention $^{(38)}$, similar to the present findings. Also, the shift in ruminal VFA proportions that we observed with feeding SFO, with more propionate and less acetate, provided an additional glucogenic substrate that could have altered $\mathrm{N}$ use. In addition to improving propionate supply, supplemental SFO also could have provided another potential glucose precursor (glycerol) that could have improved $\mathrm{N}$ use. In ruminants wholly nourished by intra-gastric infusion, supplementation with glucogenic precursors improved $\mathrm{N}$ retention ${ }^{(39,40)}$. This suggests that providing glucogenic precursors can potentially spare amino acids from being used for gluconeogenesis, thus making more amino acids available for protein accretion. Raggio et al. ${ }^{(41)}$ observed a decrease in whole-body leucine oxidation when lactating cows received intra-ruminal infusions of propionate, providing further evidence of a sparing effect of glucogenic precursors on amino acids.

A major objective of the present study was to determine the effects of feeding SFO as a defaunating agent on urea-N transfer to the GIT and the anabolic utilisation of the recycled urea$\mathrm{N}$ in lambs. The present data on urea-N recycling kinetics offer interesting insights into additional potential mechanisms by which ruminal defaunation could improve $\mathrm{N}$ utilisation. The UER was similar in $-\mathrm{SFO}$ and + SFO lambs, reflecting the similar $\mathrm{N}$ intakes, as $\mathrm{N}$ intake and UER are positively correlated $^{(8,9)}$. However, the GER, when expressed in absolute amounts or as a proportion of UER, was higher in $+\mathrm{SFO}$ lambs compared with - SFO lambs. Concomitant with these changes in the GER, urinary urea-N elimination when expressed in absolute amounts or as a proportion of UER was lower in + SFO lambs when compared with - SFO lambs. Also, although there were no differences between - SFO and + SFO lambs in the absolute amounts of ROC, the GER:ROC ratio tended to be lower in +SFO lambs compared with - SFO lambs. When taken together, these data clearly indicate that increased urea-N recycling to the GIT is also a major contributor to the improved $\mathrm{N}$ utilisation that has been consistently observed in defaunated ruminants. In our previous study, partial defaunation by feeding SFO was associated with a higher proportion of endogenous urea-N production being recycled to the GIT; however, $\mathrm{N}$ intake was lower in partially defaunated sheep compared with faunated sheep in that study ${ }^{(2)}$. Because of the positive correlation between $\mathrm{N}$ intake and hepatic output of urea- $\mathrm{N}^{(8,9)}$, data on urea-N recycling kinetics were confounded due to these differences in $\mathrm{N}$ intake. In the present study, $\mathrm{N}$ intake did not differ due to feeding SFO, thus allowing more definitive conclusions to be made on the effects on urea-N kinetics of feeding SFO as a defaunating agent.

Endogenous urea-N can diffuse through all compartments of the $\mathrm{GIT}^{(1)}$, and although the $\left[{ }^{15} \mathrm{~N}^{15} \mathrm{~N}\right]$ urea infusion technique that was used in the present study cannot distinguish between urea-N transfer to the fore-stomach and post-stomach compartments, measurements of urea-N recycling to the GIT obtained using arterio-venous preparations indicated that in concentrate-fed ruminants (as in the present study), 65-76\% of urea-N transfer to the GIT entered the fore-stomach ${ }^{(10,42)}$. It is urea-N that is transferred to the fore-stomach that can provide additional degradable $\mathrm{N}$ than be incorporated into microbial protein, thus contributing amino acids to the host animal after intestinal digestion. In the present study, however, we did not measure the direct incorporation of recycled ${ }^{15} \mathrm{~N}$ into microbial protein; rather, we measured anabolic utilisation (UUA) as part of the isotopic technique, in addition to estimating microbial NAN supply based on urinary excretion of $\mathrm{PD}^{(27)}$. The anabolic utilisation of recycled urea-N within the GIT, particularly the rumen, is assumed to be predominantly as sequestration of liberated $\mathrm{NH}_{3}-\mathrm{N}$ into microbial protein as most of the recycled urea-N first passes through the microbial $\mathrm{N}$ pool ${ }^{(19)}$, but other potential anabolic uses within the body could include amination and transamination reactions ${ }^{(19)}$. The ability to partition how much of the GER is directed towards anabolic and catabolic fates is a major 
advantage of the isotopic technique; however, a limitation is that UUA is calculated as the difference between GER and $(\mathrm{ROC}+\mathrm{UFE})$. Because faecal ${ }^{15} \mathrm{~N}$ enrichments failed to attain a definite plateau, UFE was probably underestimated; as such UUA was probably overestimated, so our data on UUA should be interpreted somewhat cautiously. However, when we used a curve fitting approach using the daily faecal ${ }^{15} \mathrm{~N}$ enrichments over the $4 \mathrm{~d}$ isotopic infusions (data not shown) to estimate plateau (maximum) enrichments, the measured 'plateau' enrichments were only 3.1-6.3\% lower than the mathematically derived 'plateau' enrichments. This suggests that UUA was only slightly overestimated. Others ${ }^{(19,43)}$ have also reported a failure of faecal ${ }^{15} \mathrm{~N}$ enrichments to attain a definite plateau with $4 \mathrm{~d}$ isotopic infusions, so future studies should consider isotopic infusions longer than $4 \mathrm{~d}$. For + SFO lambs, 0.546 of GER was directed towards anabolic fates, compared with only 0.456 for - SFO lambs. Furthermore, the ROC:GER ratio was 0.082 units lower for +SFO lambs compared with - SFO lambs, suggesting that more of the GER was used for productive purposes in + SFO lambs compared with - SFO lambs. In support of our findings of the improved productive use of recycled urea-N in partially defaunated lambs, microbial NAN supply was $27-41 \%$ greater in +SFO lambs compared with - SFO lambs. It is plausible that urea-N that was recycled to the rumen could have buffered the rumen from the lower $\mathrm{NH}_{3^{-}}$ $\mathrm{N}$ concentrations prevailing in $+\mathrm{SFO}$ lambs, thus providing additional $\mathrm{N}$ that could be used for microbial protein synthesis. Additionally, because fat provides little energy for microbial growth ${ }^{(44)}$, the positive response in intestinal microbial NAN flow when ruminal protozoal populations are decreased has also been attributed to decreased protozoal predation on bacteria and decreased competition from protozoa for growth substrates ${ }^{(4)}$. In calculating microbial NAN supply, we used purine $\mathrm{N}: \mathrm{N}$ ratios that were determined in bacteria; however, microbial NAN supply in faunated and, to a much smaller extent, partially defaunated lambs was constituted of both bacterial and protozoal N. Because the purine $\mathrm{N}: \mathrm{N}$ ratio has been reported to be higher for bacteria than for protozoa ${ }^{(45)}$ and only the purine $\mathrm{N}$ :bacterial $\mathrm{N}$ ratio was used to calculate microbial NAN supply, it is possible that microbial NAN supply was underestimated particularly in faunated lambs ${ }^{(32)}$. Nonetheless, despite these limitations, our data support previous findings of a greater microbial NAN flow to the intestine when ruminal protozoal populations are decreased ${ }^{(4,32)}$.

The major mechanism that could be responsible for the greater urea-N transfer to the GIT that we observed in partially protozoa-free lambs is plausibly the lower ruminal $\mathrm{NH}_{3}-\mathrm{N}$ concentration that was observed in these lambs compared with faunated lambs. Elevating ruminal concentration of $\mathrm{NH}_{3} \mathrm{~N}$ has been demonstrated to reduce urea- $\mathrm{N}$ transfer from blood into the rumen ${ }^{(6)}$. Also, other evidence indicates that the transepithelial movement of urea-N by passive diffusion into the rumen is facilitated by bacterial urease activity, which maintains a favourable concentration gradient ${ }^{(6)}$. Cheng \& Wallace $^{(7)}$ demonstrated that urease activity in ruminal contents was negatively correlated with ruminal $\mathrm{NH}_{3}-\mathrm{N}$ concentration. Because feeding SFO to partially defaunate the rumen resulted in a lower ruminal $\mathrm{NH}_{3}-\mathrm{N}$ concentration, this could have facilitated the transfer of a greater proportion of UER to the GIT in + SFO lambs compared with - SFO lambs. In addition, the change in propionate supply could also have altered urea-N transfer to the GIT. Feeding SFO to partially defaunate the rumen increased ruminal concentrations of propionate and, presumably, the absorption of propionate from the rumen, as this is a concentration-dependent process ${ }^{(46)}$ Propionate supplementation via intra-ruminal ${ }^{(47)}$ or intraabomasal $^{(48)}$ infusion in sheep was associated with greater urea-N recycling to the GIT and $\mathrm{N}$ retention. The mechanism by which propionate increases urea-N recycling to the GIT is unclear, but it may be related to an alteration in ruminal bacterial activities and metabolism ${ }^{(47)}$ or changes in ruminal epithelial surface area and/or permeability ${ }^{(49)}$, as propionate has been shown to stimulate epithelial cell proliferation ${ }^{(50)}$.

Increasing ruminal energy availability by feeding PB compared with DRB decreased urinary urea-N and increased $\mathrm{N}$ retention, supporting previous studies ${ }^{(11,51)}$. These positive effects on $\mathrm{N}$ utilisation of increasing ruminal energy availability have been partly mediated via increased urea-N recycling to the rumen ${ }^{(5,10,11)}$, in addition to a greater sequestration of $\mathrm{N}$ into microbial protein that is then available for intestinal digestion ${ }^{(52)}$. Surprisingly, in the present study, all the major dependent variables quantifying urea-N recycling kinetics (i.e. UER, GER, UUA and ROC) were unaffected by barley grain processing, contradicting previous studies $(10,11)$ The magnitude of urea-N transfer across the ruminal wall appears to be regulated by many intra-ruminal factors, including ruminal $\mathrm{pH}^{(6)}$. In the present study, lambs that fed $\mathrm{PB}$ exhibited a lower ruminal $\mathrm{pH}$ compared with those fed DRB. A more acidic ruminal environment in lambs fed PB could have decreased bacterial urease activity in the rumen ${ }^{(53)}$, which, in turn, might have impaired urea-N transfer due to an unfavourable concentration gradient. Also, new evidence obtained using an in vitro isolated ruminal epithelium model indicates that urea- $\mathrm{N}$ transport is inhibited at luminal $\mathrm{pH}<6.0^{(54)}$, and mean $\mathrm{pH}$ in lambs fed $\mathrm{PB}$ was 5.8 compared with 6.0 for those fed DRB. Another surprising observation from the present study was that feeding PB did not stimulate microbial NAN supply when compared with feeding DRB, contradicting previous studies ${ }^{(10,11)}$. It is well established that the amount of microbial protein that is synthesised in the rumen is largely driven by the availability of energy from RFC. In the present study, in situ measurements of ruminal starch digestion clearly indicate that starch digestion was greater for $\mathrm{PB}$ compared with DRB. Also, total tract starch digestion was greater in lambs fed $\mathrm{PB}$ compared with those fed DRB. Together, these observations would suggest that, quantitatively, ruminal energy supply was greater with $\mathrm{PB}$ compared with DRB, so it is not clear why microbial NAN supply was not stimulated with PB. Because the diets that were fed in the present study contained only $16 \mathrm{~g} \mathrm{~N} / \mathrm{kg} \mathrm{DM}$, it is likely that the rumen was limited in both $\mathrm{NH}_{3}-\mathrm{N}$ and amino acids to support microbial growth. Feeding PB to increase ruminal ATP availability when $\mathrm{NH}_{3}-\mathrm{N}$ and amino acids were potentially in short supply could have limited the 
use of the additional ATP for microbial protein synthesis ${ }^{(55)}$. In that situation, the additional ATP could have been directed towards non-growth functions, a phenomenon referred to as energy spilling ${ }^{(55)}$. In addition, Russell \& Wilson ${ }^{(56)}$ observed inhibitory effects on microbial protein synthesis when ruminal $\mathrm{pH}$ was $<6 \cdot 2$, and this was partly attributed to increased energy spilling ${ }^{(55)}$. In the present study, it is plausible that the more acidic ruminal environment in lambs fed PB could have compromised microbial growth by increasing energy spilling.

The presence of carrier-mediated, facilitative UT-B proteins has been demonstrated in the rumen of bovine ${ }^{(57,58)}$ and ovine $^{(8)}$, and these UT-B proteins have been suggested to facilitate urea-N flux into the GIT lumen ${ }^{(1)}$. Our data indicate that changes in urea-N transfer to the GIT as a result of feeding SFO occurred without concomitant changes in UT-B expression, suggesting that the effects of ruminal $\mathrm{NH}_{3}-\mathrm{N}$ and propionate on urea- $\mathrm{N}$ transfer are probably not mediated through changes in UT-B expression. Recently, Simmons et $a l .{ }^{(59)}$ reported differences in UT-B expression between forage- and concentrate-fed steers, but ruminal $\mathrm{NH}_{3}-\mathrm{N}$ concentration was unaltered, and changes in ruminal VFA profiles were minimal. The limited research that is available on dietary regulation of UT expression in ruminal epithelium is equivocal $^{(8,57,58)}$, and additional research is needed to delineate the effects of diet and ruminal metabolites on UT expression.

In conclusion, collectively, these results provide the first major evidence that, at similar $\mathrm{N}$ intakes, the improved $\mathrm{N}$ utilisation that is typically observed in partially defaunated ruminants is partly mediated by an increase in urea-N transfer to the GIT and its anabolic use. This increase in urea-N recycling to the GIT in partially defaunated ruminants could be partly mediated by the decrease in ruminal $\mathrm{NH}_{3}-\mathrm{N}$ level, which has been demonstrated to stimulate transepithelial urea-N transfer. However, feeding SFO increased energy intake, in addition to altering the profile of energy metabolites entering portal blood from the rumen, and these changes in energy intake and energy metabolites could also be partly responsible for the observed changes in urea-N recycling and $\mathrm{N}$ utilisation. Although partial defaunation increased urea-N recycling to the GIT, the response was not augmented by increasing the amount of energy that is derived from carbohydrate fermentation in the rumen.

\section{Acknowledgements}

The present study was supported by a research grant from the Natural Sciences and Engineering Research Council of Canada held by T. M. The authors thank Réal Lepage and staff of the Livestock Research Building (University of Saskatchewan) for assistance with animal care, and Jason Marshall for assistance with quantitative PCR. T. M. and K. D. designed the research (i.e. conception of the project, development of overall research plan and study oversight). K. D. conducted the research, analysed data and performed statistical analysis. T. M. and K. D. wrote the manuscript, and T. M. had the primary responsibility for the final content of the manuscript.
Both authors read and approved the final manuscript. There are no conflicts of interest.

\section{References}

1. Lapierre H \& Lobley GE (2001) Nitrogen recycling in the ruminant: a review. J Dairy Sci $\mathbf{8 4}$, E223-E236.

2. Kiran D \& Mutsvangwa T (2010) Effects of partial ruminal defaunation on urea-nitrogen recycling, nitrogen metabolism, and microbial nitrogen supply in growing lambs fed low or high dietary crude protein concentrations. J Anim Sci 88, 1034-1047.

3. Firkins JL, Yu Z \& Morrison M (2007) Ruminal nitrogen metabolism: perspectives for integration of microbiology and nutrition for dairy. J Dairy Sci 90, E1-E16.

4. Jouany JP (1996) Effect of rumen protozoa on nitrogen utilization by ruminants. $J$ Nutr 126, 1335S-1346S

5. Kennedy PM \& Milligan LP (1980) The degradation and utilization of endogenous urea in the gastrointestinal tract of ruminants: a review. Can J Anim Sci 60, 205-221.

6. Rémond D, Meschy F \& Boivin R (1996) Metabolites, water and mineral exchanges cross the rumen wall: mechanisms and regulation. Ann Zootech 45, 97-119.

7. Cheng KJ \& Wallace RJ (1979) The mechanism of passage of endogenous urea through the rumen wall and the role of ureolytic epithelial bacteria in the urea flow. BrJ Nutr $\mathbf{4 2}$, 553-557.

8. Marini JC, Klein JDM, Sands JM, et al. (2004) Effect of nitrogen intake on nitrogen recycling and urea transporter abundance in lambs. J Anim Sci 82, 1157-1164.

9. Wickersham TA, Titgemeyer EC, Cochran RC, et al. (2009) Effect of undegradable intake protein supplementation on urea kinetics and microbial use of recycled urea in steers consuming low-quality forage. Br J Nutr 101, 225-232.

10. Huntington GB (1989) Hepatic urea synthesis and site and rate of urea removal from blood of beef steers fed alfalfa hay or a high concentrate diet. Can J Anim Sci 69, 215-223.

11. Theurer CB, Huntington GB, Huber JT, et al. (2002) Net absorption and utilization of nitrogenous compounds across ruminal, intestinal, and hepatic tissues of growing beef steers fed dry-rolled or steam-flaked sorghum grain. J Anim Sci 80, 525-532.

12. Russell JB (1998) Strategies that ruminal bacteria use to handle excess carbohydrate. J Anim Sci 76, 1955-1963.

13. Koenig KM, Beauchemin KA \& Rode LM (2003) Effect of grain processing and silage on microbial protein synthesis and nutrient digestibility in beef cattle fed barley-based diets. J Anim Sci 81, 1057-1067.

14. Eadie JM, Hyldgaard-Jensen J, Mann SO, et al. (1970) Observation on the microbiology and biochemistry of the rumen in cattle given different quantities of a pelleted barley ration. Br J Nutr 24, 157-177.

15. Kiran D \& Mutsvangwa T (2007) Effects of barley grain processing and dietary ruminally-degradable protein on urea-nitrogen recycling and nitrogen metabolism in growing lambs. J Anim Sci 85, 3391-3399.

16. Canadian Council on Animal Care (1993) Guide to the Care and Use of Experimental Animals, vol. 1. Ottawa: Canadian Council on Animal Care.

17. Ivan M, Mir PS, Koenig KM, et al. (2001) Effects of dietary sunflower seed oil on rumen protozoa population and tissue concentration of conjugated linoleic acid in sheep. Small Rumin Res 41, 215-227.

18. Ogimoto K \& Imai S (1981) Atlas of Rumen Microbiology. Tokyo: Japan. Japan Scientific Societies Press. 
19. Lobley GE, Bremner DM \& Zuur G (2000) Effects of diet quality on urea fates in sheep as assessed by refined, noninvasive $\left[{ }^{15} \mathrm{~N}^{15} \mathrm{~N}\right]$ urea kinetics. Br J Nutr 84, 459-468.

20. Yu P, Christensen DA \& McKinnon JJ (2003) Effect of variety and maturity stage on chemical composition, carbohydrate and protein subfractions, in vitro rumen degradability and energy values of timothy and alfalfa. Can J Anim Sci 83, 279-290.

21. Association of Official Analytical Chemists (1995) Association of Official Analytical Chemists, 18th ed. Arlington, VA: Association of Official Analytical Chemists.

22. Van Soest PJ, Robertson JB \& Lewis BA (1991) Methods for dietary fiber, neutral detergent fiber and non-starch polysaccharides in relation to animal nutrition. J Dairy Sci $\mathbf{7 4}$, 3583-3597.

23. Soita HW, Fehr M, Christensen DA, et al. (2005) Effects of corn silage particle length and forage: concentrate ratio on milk fatty acid composition in dairy cows fed supplemental flaxseed. J Dairy Sci 88, 2813-2819.

24. Erwin ES, Marco GJ \& Emery EM (1961) Volatile fatty acids analysis of blood and rumen fluid by gas chromatography. J Dairy Sci 44, 1768-1771.

25. Broderick GA \& Kang JH (1980) Automated simultaneous determination of ammonia and total amino acids in ruminal fluid and in vitro media. J Dairy Sci 63, 64-75.

26. Makkar HPS \& Becker K (1999) Purine quantification in the digesta from ruminant animals by spectrophotometric and HPLC methods. Br J Nutr 81, 107-111.

27. Chen XB \& Gomes MJ (1992) Estimation of Microbial Protein Supply to Sheep and Cattle Based on Urinary Excretion of Purine Derivatives - An Overview of the Technical Details. Aberdeen: International Feed Resources Unit, Rowett Research Institute. http://www.macaulay.ac.uk/IFRU/pdf/ chema.pdf

28. Marsh WH, Fingerhunt B \& Kirsch E (1957) Determination of urea $\mathrm{N}$ with the diacetyl method and an automatic dialyzing apparatus. Am J Clin Pathol 28, 681-688.

29. Archibeque SL, Burns JC \& Huntington GB (2001) Urea flux in beef steers: effects of forage species and nitrogen fertilization. J Anim Sci 79, 1937-1943.

30. SAS Institute (2004) SAS/STAT 9.1 User's Guide Version. Cary, NC: SAS Institute, Inc.

31. Wang Z \& Goonewardene LA (2004) The use of MIXED models in the analysis of animal experiments with repeated measures data. Can J Anim Sci 84, 1-11.

32. Koenig KM, Newbold CJ, McIntosh FM, et al. (2000) Effects of protozoa on bacterial nitrogen recycling in the rumen. J Anim Sci 78, 2431-2445.

33. Newbold CJ, Chamberlain DG \& Williams AG (1986) The effects of defaunation on the metabolism of lactic acid in the rumen. J Sci Food Agric 37, 1083-1090.

34. Ivan M, Mir PS, Mir Z, et al. (2004) Effects of dietary sunflower seeds on rumen protozoa and growth of lambs. BrJ Nutr 92, 303-310.

35. Oldick BS \& Firkins JL (2000) Effects of degree of fat saturation on fiber digestion and microbial protein synthesis when diets are fed twelve times daily. J Anim Sci $\mathbf{7 8}$, 2412-2420.

36. Faichney GJ, Gordon GLR, Welch RJ, et al. (2002) Effect of dietary free lipid on anaerobic fungi and digestion in the rumen of sheep. Aust J Agric Res 53, 519-527.

37. Yang WZ, Beauchemin KA \& Rode LM (2000) Effects of barley grain processing on extent of digestion and milk production of lactating cows. J Dairy Sci 83, 554-568.
38. Schroeder GF, Titgemeyer EC, Awawdeh MS, et al. (2006) Effects of energy source on methionine utilization by growing steers. J Anim Sci 84, 1505-1511.

39. Chowdhury SA, Ørskov ER, De FD, et al. (1997) Protein utilization during energy undernutrition in sheep sustained by intragastric infusion: effects of protein infusion level, with or without sub-maintenance amounts of energy from volatile fatty acids, on energy and protein metabolism. Br J Nutr $\mathbf{7 7}$, 565-576.

40. Ørskov ER, Meehan DE, MacLeod NA, et al. (1999) Effects of glucose supply on fasting nitrogen excretion and effect of level and type of volatile fatty acid on response to protein infusion in cattle. BrJ Nutr 81, 389-393.

41. Raggio G, Lobley GE, Lemosquet S, et al. (2006) Effect of casein and propionate supply on whole body protein metabolism in lactating cows. Can J Anim Sci 86, 81-89.

42. Reynolds CK \& Huntington GB (1988) Partition of portaldrained visceral net flux in beef steers. 1. Blood flow and net flux of oxygen, glucose and nitrogenous compounds across stomach and post-stomach tissues. Br J Nutr 60 , $539-551$.

43. Sunny NE, Owens SL, Baldwin RL, et al. (2007) Salvage of blood urea nitrogen in sheep is highly dependent upon plasma urea concentration and the efficiency of capture within the digestive tract. J Anim Sci 85, 1006-1013.

44. Wu Z \& Palmquist DL (1991) Synthesis and biohydrogenation of fatty acids by ruminal microorganisms in vitro. J Dairy Sci 74, 3035-3046.

45. Firkins JL, Berger LL, Merchen NR, et al. (1987) Ruminal nitrogen metabolism in steers as affected by feed intake and dietary urea concentration. J Dairy Sci 70, 2302-2311.

46. Van Soest PJ (1994) Function of the ruminant forestomach. In Nutritional Ecology of the Ruminant, 2nd ed., pp. 230-252. Ithaca, NY: Cornell University Press.

47. Savary-Auzeloux IC, Majdoub L, LeFloc'h N, et al. (2003) Effects of intraruminal propionate supplementation on nitrogen utilisation by the portal-drained viscera, the liver and the hindlimb in lambs fed frozen rye grass. Br J Nutr 90, 939-952.

48. Kim H-S, Choung JJ, Dhamberlain D, et al. (1999) Effect of propionate on ovine urea kinetics. In VIIIth International Symposium on Protein Metabolism and Nutrition, p. 57 [G Lobley, A White and JC MacRae, editors]. Aberdeen: Aberdeen United Kingdom, Wageningen Press.

49. Abdoun K, Stumpff F \& Martens H (2007) Ammonia and urea transport across the rumen epithelium: a review. Anim Health Res Rev 7, 43-59.

50. Sakata T \& Tamate H (1978) Rumen epithelial cell proliferation accelerated by rapid increase in intraruminal butyrate. J Dairy Sci 61, 1109-1113.

51. Taniguchi K, Huntington GB \& Glenn BP (1995) Net nutrient flux by visceral tissues of beef steers given abomasal and ruminal infusions of casein and starch. J Anim Sci $\mathbf{7 3}$ 236-249.

52. Theurer CB, Huber JT, Delgado-Elorduy A, et al. (1999) Invited review: summary of steam-flaking corn or sorghum grain for lactating dairy cows. J Dairy Sci $\mathbf{8 2}$ 1950-1959.

53. Gozho GN, Hobin MR \& Mutsvangwa T (2008) Interactions between barley grain processing and source of supplemental dietary fat on nitrogen metabolism and urea-nitrogen recycling in dairy cows. J Dairy Sci 91, 247-259.

54. Abdoun K, Stumpff F, Rabbani I, et al. (2010) Modulation of urea transport across sheep rumen epithelium in vitro by 
SCFA and $\mathrm{CO}_{2}$. Am J Physiol Gastrointest Liver Physiol 298 G190-G202.

55. Russell JB (2007) The energy spilling reactions of bacteria and other organisms. I Mol Microbiol Biotechnol 13, $1-11$.

56. Russell JB \& Wilson DB (1996) Why are ruminal cellulolytic bacteria unable to digest cellulose at low pH? J Dairy Sci 79, 1503-1509.

57. Stewart GS, Graham C, Cattell SS, et al. (2005) UT-B is expressed in bovine rumen: potential role in ruminal urea transport. Am J Physiol Regul Integr Comp Physiol 289, R605-R612.

58. Marini JC \& Van Amburgh ME (2003) Nitrogen metabolism and recycling in Holstein heifers. J Anim Sci 81, $545-552$.

59. Simmons NL, Chaudhry AS, Graham C, et al. (2009) Dietary regulation of ruminal bovine UT-B urea transporter expression and localization. J Anim Sci 87, 3288-3299.

60. National Research Council (1985) Nutrient Requirements of Sheep. Washington, DC: National Academy Press. 